\title{
Correction to: Biology and Pragmatism: The Organism-Environment Bond
}

\section{Trevor Pearce. Pragmatism's Evolution: Organism and Environment in American Philosophy. Chicago and London: University of Chicago Press, 2020. xiii +365 pp}

\section{David Depew ${ }^{1}$}

Published online: 1 June 2021

(c) Springer Nature B.V. 2021

\section{Correction to: Acta Biotheoretica https://doi.org/10.1007/s10441-021-09410-6}

In the original publication, the name Pearce was mistakenly processed as Peirce in the (below) three occurrences of the text.

The first of these occurs a line 3 of the paragraph that begins "Trevor Pearce makes clear.” It currently reads Peirce 1877, p. 6. It should read (Pearce, p. 6.)

The other two occurrences are at line 6 of the paragraph on page 2 that begins "Richard Rorty." It should be changed to Pearce, p. 337.

The final one occurs on the same page at line 7 of the paragraph that begins "On this framing." It should read Pearce.

The original article has been corrected.

Publisher's Note Springer Nature remains neutral with regard to jurisdictional claims in published maps and institutional affiliations.

The original article can be found online at https://doi.org/10.1007/s10441-021-09410-6.

David Depew

david-depew@uiowa.edu

1 University of Iowa, Iowa City, USA 